\title{
CEACAM8 Gene
}

National Cancer Institute

\section{Source}

National Cancer Institute. CEACAM8 Gene. NCI Thesaurus. Code C118588.

This gene may play a role in the modulation of immunity. 